\title{
THE EFFECT OF BEETROOT BISCUITS (Beta vulgaris) ON THE HEMOGLOBIN LEVEL OF PATIENTS WITH PULMONARY TUBERCULOSIS
}

\author{
Amila ${ }^{1}$, Evarina Sembiring ${ }^{2}$ \\ ${ }^{1}$ Bachelor of Science in Nursing Program Sari Mutiara Indonesia University, Medan, Indonesia \\ ${ }^{2}$ Public Health Sciences Sari Mutiara Indonesia University, Medan, Indonesia \\ Correspondence Address : Amila \\ Email: mila_difa@yahoo.co.id
}

\begin{abstract}
Mycobacterium tuberculosis grows by taking iron from blood, resulting in iron deficiency leading to low hemoglobin levels in patients with pulmonary tuberculosis. This study aimed to examine the effect of beetroot biscuits consumption on the increase of hemoglobin levels in patients with pulmonary tuberculosis at the Integrated Service Unit of the Pulmonary Central Hospital of North Sumatera. The research design was quasi experimental and used pre-tests and post-tests without a control approach. This study was conducted with a sample of 100 patients selected using the purposive sampling technique. Firstly, the hemoglobin level of the patients was measured. Then, beetroot biscuits were given to the patients for thirty days as the intervention. A Wilcoxon test was performed to pinpoint the differences between the pre-test and post-test results. It was found that there was a $2.01 \mathrm{gr} / \mathrm{dl}$ increase in hemoglobin after beetroot biscuits were given to patients with pulmonary tuberculosis at the Integrated Service Unit of the Pulmonary Central Hospital of North Sumatera. It was also found that the differences were significant when comparing the average level of hemoglobin before and after the intervention with a p value of 0.000 . This study suggests that doctors and nurses play important roles in constructing patients' knowledge and understanding on the importance of anemia prevention in order to improve community knowledge to use local resources to improve health outcomes.
\end{abstract}

Keywords: anemia, biscuit, beetroot, tuberculosis

\begin{abstract}
ABSTRAK
Kuman Mycobacterium tuberculosis memerlukan zat besi $(F e)$ untuk pertumbuhannya, sehingga terjadi defisiensi zat besi sebagai komponen pembentuk hemoglobin pada pasien tuberkulosis (TB) paru. Tujuan penelitian adalah untuk melihat pengaruh pemberian biskuit bit terhadap peningkatan kadar hemoglobin pada pasien TB paru di Unit Pelayanan Terpadu RS Khusus Paru Sumatera Utara. Desain penelitian adalah quasi experiment dengan pendekatan pre-test and post test without control pada 100 orang melalui purposive sampling. Sebelum intervensi pasien TB paru diukur hemoglobin, kemudian diintervensi dengan pemberian biskuit buah bit selama 30 hari. Uji Wilcoxon digunakan untuk menguji perbedaan kadar hemoglobin pre-test dan post-test pada pasien TB Paru. Hasil penelitian menunjukkan peningkatan kadar Hb setelah diberikan biskuit bit di Unit Paru Sumatera Utara sebesar $2.01 \mathrm{gr} / \mathrm{dl} .2 .00 \mathrm{gr} / \mathrm{dl}$ dan didapatkan perbedaan yang signifikan terhadap rerata kadar Hb sebelum dan setelah diberikan biskuit bit pada pasien TB Paru di Unit Pelayanan Terpadu RS Khusus Paru Sumatera Utara $(\mathrm{p}=0,000)$. Dokter dan perawat berperan penting dalam membangun pengetahuan dan pemahaman pentingnya pencegahan anemia dengan meningkatkan pengetahuan masyarakat untuk menggunakan sumber daya lokal dalam meningkatkan kesehatan.
\end{abstract}

Kata Kunci: anemia, biskuit, bit, TB paru

\section{INTRODUCTION}

Tuberculosis (TB) is an airborne infection caused by Mycobacterium tuberculosis which commonly attacks the lungs. Tuberculosis is one of the biggest mortalities and morbidity factors in the world, particularly in developing countries.
It is estimated that in 2015, there were 10.4 million new TB cases worldwide. However, the number of TB deaths and its incidence rate is continuously falling globally (Indonesian Ministry of Health, 2013). The World Health Organization (WHO) reported that an estimated nine million people suffered from TB in 2013 (WHO, 
2014). Tuberculosis is the second-most devastating infectious disease (1.5 million cases) after HIV/AIDS caused by the human immunodeficiency virus. In addition, Indonesia has the fifth-largest incidence rate of tuberculosis in the world after India, China, Nigeria, and Pakistan. The prevalence of tuberculosis in Indonesia in 2013 was $0.4 \%$ of the total population.

In 2014, the total number of accounted patients with pulmonary tuberculosis in Indonesia was 176,677 with a prevalence rate of 113 per 100,000 people. The success rate of pulmonary tuberculosis treatment in Indonesia, based on data from the Indonesian health profile, was $81.3 \%$. This number has not met the WHO target of $85 \%$. Based on these epidemiologic facts, it is necessary to put more effort towards controlling pulmonary tuberculosis in Indonesia (Indonesian Ministry of Health, 2016). Anemia is a complication that commonly occurs in patients with pulmonary tuberculosis, with a prevalence rate of around 16\%-94\% (Monjur and Rizwan, 2014).

Adzani, Dalimoenthe and Wijaya (2016) reported that anemia in adult TB patients occurred in as many as $41.18 \%$ males and $58.82 \%$ females, and $47.06 \%$ of these anemia cases were hypochromic microcytic anemia. In TB patients, anemia can manifest as chronic-disease-related anemia, anemia due to coughing blood (hemoptysis), anaemia due to malnutrition, and sideroblastic anemia as a side effect of isoniazid (Umakanth, 2017; Piso, Kriz, and Desax, 2011).

Anemia is a reduction in the oxygen-carrying capacity of the blood; this may be caused by a decrease in red blood cell (RBC) production, a reduction in haemoglobin content of the blood, or a combination of these. Anemia can be defined as a condition when the level of hemoglobin is lower than $13.0 \mathrm{~g} / \mathrm{l}$ for men, less than $12.0 \mathrm{~g} / \mathrm{l}$ for non-pregnant women, and lower than $110 \mathrm{~g} / \mathrm{l}$ for pregnant women. It is estimated that pulmonary tuberculosis will infect around 1 billion people with 70 million death cases by 2020 if it is not controlled properly (Sei et al., 2006).

Patients with pulmonary

tuberculosis are at high risk of anemia due to the infection process and their metabolism needs. Anemia in tuberculosis can be caused by the emergence of erythropoiesis disturbances by inflammatory mediators, shorter erythrocyte lifespan, iron metabolism disorder, malabsorption, and malnutrition (Amin and Bahar, 2009; Sei et al., 2006). In the case of anemia in chronic pulmonary tuberculosis, cytokines disturb the ability of the human body in utilizing iron. Furthermore, cytokines can also interfere with normal activities of erythropoietin in red blood cell production. In addition, Mycobacterium tuberculosis worsens these conditions because this bacterium needs iron $(\mathrm{Fe})$ to grow, thus resulting in iron deficiency.

Protein calories and iron malnutrition will affect the immune system and reduce body endurance towards diseases including pulmonary tuberculosis. This is because the role of protein on pulmonary tuberculosis is not only to fulfill nutritional needs, but also to improve regeneration of damaged cells and accelerate the sterilization process of the bacteria causing pulmonary tuberculosis (Gupta et al., 2009).

Dietary intake of high protein and high calories is necessary to improve the nutritional status of patients. Additionally, iron and folic acid are also necessary to prevent the emergence of anemia. Beetroot (Beta vulgaris) has many benefits. Iron and folic acid in beetroot can be used as alternatives to treat anemia in patients with pulmonary tuberculosis. In addition, beetroot is affordable and easy to get, and it is also easy to prepare. Beetroot has historically been used to treat people with anemia.

Beetroot (Beta vulgaris rubra) is an important raw material of plant origin with proven positive effects on the human body. They can be eaten raw, boiled, steamed, and 
roasted. Beetroot has many benefits, including its high iron and folic acid content. Red beetroot is also rich in mineral compounds (magnesium, sodium, potassium, iron, and copper). $100 \mathrm{gr} / 3.5 \mathrm{onz}$ of beets normally contain $0.80 \mathrm{mg}(6 \%)$ iron and $109 \mu \mathrm{g}$ folic acid. The high content of iron and folic acid in beetroots can be used as an alternative anemia treatment (Joshi and Mathur, 2010). Beetroots are rich in vitamin $C$, which helps in treating anemia because it increases iron absorption in the body (Ingle et al., 2017).

Recent studies have provided compelling evidence that beetroot ingestion offers beneficial effects for several other pathologies, such as hypertension, atherosclerosis, type 2 diabetes, and dementia (Ninfali and Angelino, 2013; Gilchrist et al., 2014; Presley et al., 2011; Vanhatalo et al., 2010; (Wootton-Beard, Moran, and Ryan, 2011)

Beetroot is also rich in phenol compounds, which have antioxidant properties. These colorful root vegetables help to protect against heart disease and certain cancers (colon cancer) (Kavalcová et al., 2015). Beetroots are rich in other valuable compounds as well, such as carotenoids (Dias, Camões, and Oliveira, 2009), glycine betaine (De Zwart et al., 2003), saponins (Atamanova et al., 2005), betacyanins (De Azeredo et al., 2009), folates (Presley et al., 2011; Jastrebova et al., 2003), betanin (De Zwart et al., 2003), polyphenols, and flavonoids (Váli et al., 2007). Therefore, beetroot ingestion can be considered a factor in cancer prevention (Kapadia et al., 1996).

Based on researchers' observations at the Sari Mutiara Medan General Hospital and the Integrated Service Unit of the Pulmonary Central Hospital of North Sumatera, the number of patients with pulmonary tuberculosis treated at the polyclinic is increasing, particularly after the implementation of national health insurance by the government. The number of patients with pulmonary tuberculosis in 2014 was 516 people, and that number increased to 612 patients in 2015. It is estimated that the number of patients who visited the polyclinic was 55 people per month. Physical examination results found that patients with pulmonary tuberculosis looked thin, weak, and pale. Many of the patients also suffered from anemia with hemoglobin levels that were relatively low (men $<13 \mathrm{gr} / \mathrm{dl}$ and women $<12 \mathrm{gr} / \mathrm{dl}$ ). It was also found that some patients had suffered from chronic pulmonary tuberculosis. Therefore, since pulmonary tuberculosis disease is chronically inflammatory, patients may feel uncomfortable, be easily fatigued, have appetite problems, and experience weight loss.

Since anemia can be treated with foods with high iron and folic acid content, it is necessary to study the use of beetroot biscuits in treating anemia. According to previous studies, beetroots have been proven to be able to increase hemoglobin levels. Based on a study conducted by Suryandari and Happinasari (2015) on a number of pregnant mothers using iron therapy and beetroots for seven days, it was found that there was a significant increase of hemoglobin levels $(p=0.009)$ after the intervention given. Priya, Malarvizhi, and Jothi (2013) found that there was a significant increase in hemoglobin levels among female adolescents after they had been given beetroot juice for a period of 20 days. Hobbs et al. (2013) conducted an experimental study on 23 male participants who received 200 gr of bread containing 100 gr beetroot, and a similar number control group who got bread without beetroot content for 7 days. It was found that bread containing beetroot could improve endothelium-independent vasodilation and reduce diastolic blood pressure.

The benefits of beetroot are not only well-known in Indonesia, but also in other countries. However, beetroot products in the market are still limited to juice and food colorants. Beetroot is less preferred because of its bitter and unpleasant taste. Although, 
it is known that beetroot biscuits have high nutritional value at affordable prices and can be consumed as snacks by the community, particularly patients with pulmonary tuberculosis.

Beetroot is also rich in carbohydrates (in the form of sugar with low protein and fat) that can be converted into energy. Moreover, iron in beetroots can also help blood transport oxygen to the brain. Beetroot can also be used in therapeutic medication, particularly clinical pathology related to oxidative and inflammation stress (Clifford et al., 2015).

It is also easy to grow and cultivate beetroot in North Sumatera and other areas throughout Indonesia. In North Sumatera, the Berastagi District is a well-known area for beetroot production. Beetroots can be consumed raw, boiled, steamed, fermented, or roasted. This plant is also used as a natural food colorant because it contains betalain compounds that are responsible for the red color of the plant. It also consumed as juice, however it can be unfavorable because of its unpleasant smell and bitter and earthy taste. Beetroots in biscuits can be an alternative method for increasing the hemoglobin levels of patients with pulmonary tuberculosis. Beetroot biscuits are easy to serve as a snack, they are transportable, and they have an attractive color. The phenomenon in the real life found that, generally, patients with pulmonary tuberculosis tend to focus on pharmacologic therapy, while blood supplement administration is considered less economical and can bring forth unwanted side effects.

Biscuits are widely-consumed baked products that can be served as breakfast to bedtime snacks. Biscuits are appreciated for their taste, aroma, convenience, and long shelf stability due to low moisture content. Recently, increasing consumer demand for healthier foods has triggered the development of cookies made with natural ingredients exhibiting functional properties and providing specific health benefits beyond those that can be gained from traditional nutrients.

Beetroot biscuits are believed to be beneficial because they can be processed to become daily snacks for patients with pulmonary tuberculosis. In addition, they are easy to serve, their color is attractive, and they can be consumed at any time. Beetroot biscuits do not only contain iron and folic acid that are useful for hemoglobin production, but are also high in calories and protein to fulfill calorie and protein needs to help the healing process of patients with pulmonary tuberculosis. High protein and calorie intake is necessary to improve patients' nutritional and iron status, while folic acid is needed to prevent anemia. Sufficient intake of calorie and protein can help accelerate the process of the growth of new cells in patients' bodies.

Based on the elaboration of the phenomenon in this section, it can be summarized that patients suffering from pulmonary tuberculosis are also vulnerable to anemia and malnutrition as a result of disease complications and side effects of anti-tuberculosis drugs. This study aimed to examine the effect of beetroot biscuits consumption on the increase of hemoglobin levels in patients with pulmonary tuberculosis at the Integrated Service Unit of the Pulmonary Central Hospital of North Sumatera.

\section{METHODS}

This study used the quasiexperimental method and pre-test and posttest design without a control approach. A total number of 100 patients were samples taken using the purposive sampling technique. The inclusion criteria were 1) patients with pulmonary tuberculosis without any accompanying diseases, 2) tuberculosis patients who were also suffering from anemia, 3) hemoglobin level of below $14 \mathrm{~g} / \mathrm{dl}$ (normal 14-18 gr/dl) for men and below 12g/dl (normal 12-16 gr/dl) for women, and 4) those with no blood supplement consumption. 
The research dependent variable was haemoglobin levels, and the research independent variable (free) was the beetroot biscuits (Beta vulgaris). The instrument used to collect the characteristic data of respondents was an assessment form including demographic data such as age, sex, weight, and body mass index (BMI) obtained from the medical record and observation during the documentation study phase. Hemoglobin level data was measured by using a hemoglobin measurement tool called a hemacromax with Indonesian Red Cross standards in collaboration with laboratory staffs.

This study was conducted between May 2017 and September 2017, at the Integrated Service Unit of the Pulmonary Central Hospital of North Sumatera. The study was conducted after receiving written approval from the ethical committee at the Faculty of Nursing of the University of Sumatera Utara with the approval number $1210 / \mathrm{V} / \mathrm{SP} / 2017$ from the Head of Education and Research Division of the Integrated Service Unit of the Pulmonary Central Hospital of North Sumatera. The study was also conducted with consideration for ethical issues, such as self determination, privacy and anonymity, beneficience, maleficience, and justice. All participants were aware of the purpose of this study, and their agreement to participate was supported by a signed informed consent document. The patients were interviewed by the researcher, who then determined their eligibility.

Before the intervention was given to the patients, beetroot biscuits had their contents analysed at three laboratories, namely the Laboratory of BARISTAN of the Department of Industry of Medan City, the Laboratory of the Head Office of the Agricultural Industry in Bogor City, and the Food and Pharmaceutical Laboratory of the University of Sumatera Utara in Medan. The analysis was done to assess the nutrition values of iron, folic acid, carbohydrate, protein, fat, and fiber in beetroot biscuits.
In the process of making beetroot biscuits, fresh beetroots were washed thoroughly, boiled to reduce their bitter and earthy taste, and then grated. The ingredients for one serving of beetroot biscuits were 500 gr beetroot flour, $400 \mathrm{gr}$ fresh beetroot (extracted to become $175 \mathrm{cc}$ ), 3 eggs, 125 gr butter, and 100 gr sugar. All ingredients were mixed and baked in an oven. One portion of dough could produce 50 beetroot biscuits (the weight of each biscuit $=20$ gr).

After that, researchers assessed and calculated the nutritional value of the biscuits in order to determine if the needs of pulmonary tuberculosis patients who also suffered from anemia could be fulfilled. It was found that one biscuit contained as much as $22.2 \mathrm{mg} / 20$ gram $=22.2 \mathrm{mg} / 20,000$ $\mathrm{mg}=1.11 \mathrm{mg}$ iron, and $2.30 \mathrm{mg} / 20$ gram $=$ $2.30 \mathrm{mg} / 20,000 \mathrm{mg}=0.011 \mathrm{mg}$ folic acid.

Before performing the intervention, hemoglobin levels were measured in patients with pulmonary tuberculosis at the Integrated Service Unit of the Pulmonary Central Hospital of North Sumatera. If the hemoglobin level of male patients was lower than $14 \mathrm{gr} / \mathrm{dl}$ and female patients' hemoglobin level was lower than $12 \mathrm{gr} / \mathrm{dl}$, it indicated that the patients were suffering from anemia and could be included as respondents. Then, the intervention was given to each respondent. Each respondent ate 13 beetroot biscuits every day for a period of 30 days. After the intervention period, patients' hemoglobin level was measured again (post-test) by using a hemacromax tool that had been calibrated in order to determine the effect of beetroot biscuits on the change of patients' hemoglobin levels.

The data in this research were obtained in the form of nominal data, including data on sex and body mass index. Numerical data were age and the results of hemoglobin level tests. Data and information that were obtained through pretests and post-tests were then analyzed using univariate and bivariate analyses using a computer application. The 
univariate analysis was conducted to calculate the mean, standard deviation, minimum-maximum, and frequency distribution of each of the variables studied. Before determining the inferential statistic, the normality data was examined. A normality test was performed on numerical data (hemoglobin levels) by using the Kolmogorov Smirnov test. The results of the data were not normal, thus a bivariate analysis was conducted using the Wilcoxon test to figure out the difference between the pre-test and post-test results. The data analyzed were presented in the form of tables and narrated to facilitate the delivery of information about the research results.

\section{RESULTS}

Table 1. Distribution of Respondents of Pulmonary Tuberculosis Suffering from Anemia Based on Age

\begin{tabular}{cccc}
\hline Variable & Mean & $\begin{array}{c}\text { Standar } \\
\text { deviation }\end{array}$ & $\begin{array}{c}\text { Min- } \\
\text { Max }\end{array}$ \\
\hline Age & 44.75 & 17.59 & $18-78$ \\
\hline
\end{tabular}

Based on the analysis shown in Table 1, it was found that the average age of the respondents at the Integrated Service Unit of the Pulmonary Central Hospital of North Sumatera was 44.75 years old $(\mathrm{SD}=$ 17.59), with the youngest respondent being18 years old and the oldest being 78 years old.

Table 2 Distribution of Respondents Based on Sex and Body Mass Index

\begin{tabular}{lll}
\hline Variable & $\sum$ & $\%$ \\
\hline Sex & & \\
\hline Male & 52 & 52 \\
Female & 48 & 48 \\
\hline Body Mass Index & & \\
\hline Underweight & 29 & 29 \\
Normal & 61 & 61 \\
Overweight & 9.0 & 9.0 \\
Obesity & 1.0 & 1.0 \\
\hline
\end{tabular}

Based on the analysis shown in Table 2, it was found that the patients at the Integrated Service Unit of the Pulmonary Central Hospital of North Sumatera were predominantly male $(52 \%)$, with females making up a smaller percentage (48\%). Based on the analysis shown in Table 2, it can be seen that the body mass index of patients with pulmonary tuberculosis at the Pulmonary Central Hospital of North Sumatera was mostly normal (61\%). There were 29 underweight respondents (29\%), 9 overweight respondents (9\%), and 1 obese respondent (1\%).

Table 3. Distribution of Patients with Pulmonary Tuberculosis Suffering from Anemia based on Hemoglobin Level Scores of Pre-Test and Post-Test

\begin{tabular}{lccc}
\hline Variable & Mean & $\begin{array}{l}\text { Standar } \\
\text { deviation }\end{array}$ & $\begin{array}{c}\text { Min- } \\
\text { Max }\end{array}$ \\
\hline $\begin{array}{c}\text { Hemoglobin } \\
\text { Level Before } \\
\text { Intervention }\end{array}$ & 11.37 & 1.54 & $6-13$ \\
\hline $\begin{array}{c}\text { Hemoglobin } \\
\text { Level After }\end{array}$ & 13.38 & 1.61 & $9-16$ \\
Intervention & & & \\
\hline
\end{tabular}

Table 3 shows the average score of hemoglobin levels from pre-tests and posttests. The average score of hemoglobin levels in patients with pulmonary tuberculosis at the Integrated Service Unit of the Pulmonary Central Hospital of North Sumatera before the intervention was 11.37 $\mathrm{gr} / \mathrm{dl}$. After the intervention, the average hemoglobin level was $13.38 \mathrm{gr} / \mathrm{dl}$ (SD = 1.63), while the lowest and highest scores were $9 \mathrm{gr} / \mathrm{dl}$ and $16 \mathrm{gr} / \mathrm{dl}$, respectively.

Table 4. Analysis Result of Hesmoglobin Level Differents from Pre-Test and Post-Test

\begin{tabular}{lc}
\hline Statistical Test $^{\mathrm{a}}$ \\
\hline & Hb Post-Hb Pre \\
$\mathrm{Z}$ & $-8.699^{\mathrm{b}}$ \\
\hline Asymp. Sig. (2-tailed) & .000 \\
\hline
\end{tabular}


Table 4 shows the results of the Wilcoxon test. It shows that there was a significant average difference in hemoglobin levels before and after the patients at the Integrated Service Unit of the Pulmonary Central Hospital of North Sumatera were given beetroot biscuits $(\mathrm{p}=$ 0.000).

\section{DISCUSSION}

Anemia is a recognized hematological complication in patients with TB. Anemia in TB patients is related to chronic inflammation, where erythropoiesis is inhibited by cytokines and iron metabolism is altered, which results in mild to moderate degrees of anemia (Muhammad, 2005; Weiss and Goodnought, 2005). Hematological changes that occur are often associated with the body's immune response to the TB infection. However, the prevalence, extent, and types of anemia varied among different populations. This study found that the patients at the Integrated Service Unit of the Pulmonary Central Hospital of North Sumatera were predominantly male. A similar study conducted in Korea showed a wide range of anemia prevalence from $16 \%$ to $94 \%$ (Sei et al., 2006b). Another study in India showed prevalence of anemia in almost all (100\%) male patients and $82.3 \%$ of female patients (Umakanth, 2017). While in Pakistan, prevalence of anemia in adult lung TB patients was found to have occurred in as many as $55 \%$ of male patients and $53 \%$ of female patients (Shafee et al., 2014). Additionally, anemia had been observed in $89.2 \%$ of TB patients in Brazil (Oliveira et al., 2014). This diversity in results may be due to the presence of another coexisting disease (Adzani et al., 2016). Almost all chronic infections were associated with anemia, however TB operates different pathogenesis and suppresses erythropoiesis with various cytokines. This pulmonary TB also causes micronutrient deficiency and malabsorption syndrome, which further worsen the severity of anemia (Isanaka et al., 2012).

The mean age for male and female lung TB patients in this study was 44 years old with a range of $18-78$ year old patients. The study reported that most TB patients with anemia were over 16 years old (Karoum et al., 2009). This is consistent with previous studies that indicate the lung TB is most commonly found in patients at a young age or productive age. According to Glaziou et al. (2015), most TB patients with anemia (88\%) were aged 15-64 years old, while Ruditya (2015) observed patients that were predominantly (71.4\%) aged $15-55$ years old. TB is a leading killer among adults in the most economically productive age groups, as well as people living with HIV (Lopez and Mathers, 2006). Even those cured from TB can be left with lifetime sequelae that substantially reduce their quality of life (Glaziou, Floyd, and Raviglione, 2015).

This study also showed that the majority of TB patients with anemia had normal BMIs although there was still a small percentage that were underweight. The correlation between tuberculosis and malnutrition can be attributed to two factors: the effect of tuberculosis on the nutritional status and the effect of malnutrition on the clinical manifestations of tuberculosis as a result of immunological impairment (Umakanth, 2017). The result of this study is not consistent with a small study conducted in Srilanka which revealed that more than $50 \%$ of TB cases were associated with being underweight (Umakanth and Rishikesavan, 2017), while a study by Oliveira et al. (2014) documented $68.7 \%$ of pulmonary TB patients with anemia had a BMI of 18.21 $\mathrm{kg} / \mathrm{m} 2$ (underweight).

This study found that there was difference between pre-test and post-test scores of hemoglobin levels in patients with pulmonary tuberculosis at the Integrated Service Unit of the Pulmonary Central Hospital of North Sumatera. There was a $2.01 \mathrm{gr} / \mathrm{dl}$ increase in hemoglobin levels 
after beetroot biscuits were given to patients with pulmonary tuberculosis.

It was found that there was a hemoglobin level increase after the patients with pulmonary tuberculosis consumed beetroot biscuits for 30 days, which indicated that beetroot has a therapeutic effect on patients with iron deficiency. This result was supported by the results of a study by Al-Aboud (2018) about the effect of beetroots on hematology (hemoglobin), total iron binding capacity, ferritin, transferrin, serum iron, and mean corpuscular volume tests. This study was conducted on blood samples before and after 20 days of consuming dried beetroot among a group of volunteer female respondents. It was found that there was a hemoglobin level increase of around 2.4\%$11.4 \%$. Priya et al. (2013) also found that there was a significant increase in hemoglobin levels among female adolescents after the consumption of beetroot juice over a 20 day period. Indumathi and Kannikaparameswari. $\mathrm{K}$ (2014) explained that Beta vulgaris significantly improved packed cell volume (PCV), hemoglobin concentration in Red Blood Cell counts (RBCs), total lymphocyte count, and MCV.

Beetroots influence the process of red blood cell and new cell growth. It is known that fresh beetroots contain substances such as $34 \%$ folic acid to grow and replace damaged cells, $14.8 \%$ potassium to accelerate intracellular fluid balance, $13.6 \%$ fibre, $10.2 \%$ vitamin $\mathrm{C}$ to grow tissue and normalize the blood stream, $9.8 \%$ magnesium to maintain muscle functions, $1.4 \%$ tryptophan, $7.4 \%$ iron to maintain muscle function, $6.5 \%$ copper to form red blood cells, $6.5 \%$ phosphor to build strong bones, coumarin as an antitumor agent, and betacyanin as an anticancer agent (Clifford et al., 2015).

Beetroots prevent anemia by increasing red blood cell count and improving blood circulation while oxygen carries red blood cells. Anthocyanin flavonoids and all contents in beetroots are useful in red blood cell formation and are also empirically useful since beetroot is rich in iron. Iron plays an important role in red blood cell formation as it combines protein with hemoglobin, which is further combined with oxygen in forming a compound called oxy-hemoglobin. Oxyhemoglobin is the part of blood that helps transport oxygen and nutrients throughout the body. Iron deficiency can cause anemia, and this is known as iron deficiency anemia. Vitamin $\mathrm{C}$, which is another component of beetroot, can also help to cure anemia because it can improve the absorption of iron in the human body (Clifford et al., 2015; Pallavi Joshi, and Beena Mathur, 2010).

Normally, 100 gr/3.5 onz of beetroot contains $0.80 \mathrm{mg}$ iron $(6 \%)$ and $109 \mu \mathrm{g}$ folic acid (vitamin B9). The high content of iron and folate in beetroots can be used as an alternative in treating patients with anemia (Pallavi Joshi and Beena Mathur, 2010). Red beetroot has many benefits, some of which are its anti-anemia properties, as an antioxidant, to reduce high blood pressure and digestion problems, as well as to improve immunity (Murphy et al., 2011).

Foods with high nutritional value are in great demand to aid with proper functioning of body systems and derive potential health benefits. Beetroot is combined with other ingredients during processing, such as flour, sugar, egg, cheese, butter, and other ingredients containing carbohydrate, protein, and fat to allow pulmonary tuberculosis patients to receive adequate nutritional intake. The ingredients for one serving of beetroot biscuits were 500 gr beetroot flour, 400 gr fresh beetroot (extracted to become $175 \mathrm{cc}$ ), 3 eggs, 125 gr butter, and 100 gr sugar. Patients consumed beetroot biscuits for 30 days. The results of the analysis show that the beetroot biscuits contained $22.2 \mathrm{mg} / \mathrm{kg}$ iron, $2.30 \mathrm{mg} / \mathrm{kg}$ folic acid, $65.3 \%$ carbohydrate, $10.2 \%$ protein, $12.6 \%$ fat, and $1.93 \%$ fate (Laboratory of BARISTAN Department of Industry of Medan City, 
Laboratory of Head Office of Agricultural Industry, and Laboratory of Food and Pharmaceutical of University of North Sumatera, 2017).

Calorie and protein intake from beetroot biscuits is necessary to improve nutritional status, while iron and folic acid are useful to prevent anemia. The addition of red beetroot flour and grated red beetroot in the biscuit processing aims to increase the nutrient and mineral content of the biscuits. Sufficient intake of calorie and protein can help the process of new cell growth in the human body. Beetroot is rich in carbohydrates (in the form of glucose with less content of protein and fat) that easily break down to release energy, and iron which helps blood to transport oxygen to brain. Beetroot as a therapeutic treatment in clinical pathology is often associated with oxidative stress and inflammation (Clifford et al., 2015). Calories in beetroot are crucial in boosting the physical activities of pulmonary tuberculosis patients, while protein is used for tissue recovery and reparation of damaged lung tissue as a result of Mycobacterium tuberculosis. Furthermore, protein is useful as an antibody to protect the body from infections (Almatsier and Sunita, 2006).

Beetroot biscuits consumed by patients with pulmonary tuberculosis would yield better results if consumed together with Vitamin C. Iron is a mineral substance that is necessary in the process of hemopoiesis, although it is difficult absorb by the human body. In the digestion process, iron will undergo a reduction process, and it goes from ferric $\left(\mathrm{Fe}^{3+}\right)$ to ferrous $\left(\mathrm{Fe}^{2+}\right)$ to be easily absorbed. Organic acids such as ascorbic acids (Vitamin C) can help the absorption of iron by reducing ferric to become ferrous that is 3-6 times easier to be absorbed (Wruss et al., 2015).

Relevant studies related to the effect of beetroot biscuits in improving the hemoglobin level of patients with pulmonary tuberculosis have not been discovered. However, research conducted by the N.G.P. Arts and Science College at the Department of Biochemistry involved feeding mice beetroot. There was a significant increase in hemoglobin concentration from $12.25 \pm 0.5 \mathrm{gr} / \mathrm{dl}$ to $15.25 \pm 0.310 \mathrm{gr} / \mathrm{dl}$. Another study by the University of Exeter's School of Sport and Health Sciences found that one glass of beetroot juice can help recover patient stamina by around $16 \%$. The content of nitrate in beetroot juice can help the body to restore oxygen levels. Oxygen deficiency can cause fatigue and weakness in patients.

A previous study was conducted by Sembiring, Amila, and Syahpitri (2016) on patients with pulmonary tuberculosis who suffered from anemia, wherein they fed beetroot juice and high-calorie and highprotein diets to patients as the intervention. It was found that the average level of hemoglobin before the intervention was $10.7 \mathrm{gr} / \mathrm{dl}$, and after the intervention it was $13.2 \mathrm{~g} / \mathrm{dl}$. This indicated an increase of 2.5 $\mathrm{gr} / \mathrm{dl}$. The statistical test obtained a p-value of 0.000 ( $p<0.005)$. It can be concluded that there was a significant difference in hemoglobin levels before and after the intervention.

Nurses have a crucial role in enhancing patients' knowledge and understanding in preventing anemia. Nurses' involvement can be maximized by motivating nurses to continuously enhance patients' knowledge and educate the community about the local resources that can be used to improve health outcomes, in order to prevent anemia and other diseases. Additionally, since beetroot biscuits are economical and easy to prepare, they can be consumed as daily snacks by patients with pulmonary tuberculosis.

This study also discovered the confounding factors that could influence hemoglobin levels in pulmonary tuberculosis patients, one of those factors being food consumed. Nutritional components contained in the food eaten is used for arranging the formation of hemoglobin, i.e., Fe (iron) and protein. Iron contained in food will be metabolized by the 
body to become hemoglobin material. Increased food intake in pulmonary tuberculosis patients will improve albumin levels.

This study had several weaknesses. This study did not record all the food and drinks consumed before each meal, nor did it devise a method for recording the type and amount of food consumed within 24 hours (24 jam food records).

\section{CONCLUSION}

This study demonstrated that hemoglobin levels increased by $2.01 \mathrm{gr} / \mathrm{dl}$ in pulmonary tuberculosis patients who consumed beetroot biscuits over a 30 day period. Beetroot biscuits have high nutritional value and are affordable, and thus they are accessible for meals, particularly for patients with pulmonary tuberculosis. The authors would like to thank the Directorate of Research and Community Service at the Ministry of Research and Technology that funded this research.

\section{REFERENCES}

Adzani, M., Dalimoenthe, N. Z., \& Wijaya, I. (2016). Profile of Anemia on Lung Tuberculosis at Dr. Hasan Sadikin General Hospital and Community Lung Health Center Bandung. 3(1), 137-140.

Al-Aboud, N. M. (2018). ISABB Journal Of Food And Agriculture Science Effect of red beetroot (Beta vulgaris L.) intake on the level of some hematological tests in a group of female volunteers. 8(2), 10-17. https://doi.org/10.5897/ISABBJFAS2017.0070

Almatsier, \& Sunita. (2006). Prinsip Dasar Ilmu Gizi (Fundamental Principles Of Nutrition Sciences). Jakarta: Gramedia Pustaka Utama.

Amin, Z., \& Bahar, A. (2009). Ajar IlmuPenyakitDalamJilid II Edisi IV (Teaching M). Jakarta: Interna.
Atamanova, S. A., Brezhneva, T. A., Slivkin, A. I., Nikolaevskii, V. A., Selemenev, V. F., \& Mironenko, N. V. (2005). Isolation of saponins from table beetroot and primary evaluation of their pharmacological activity. Pharmaceutical Chemistry Journal, 39(12), 650-652. https://doi.org/10.1007/s11094-0060038-2

Clifford, T., Howatson, G., West, D. J., \& Stevenson, E. J. (2015). The potential benefits of red beetroot supplementation in health and disease. Nutrients, 7(4), 2801-2822. https://doi.org/10.3390/nu7042801

De Azeredo, H. M. C., Pereira, A. C., De Souza, A. C. R., Gouveia, S. T., \& Mendes, K. C. B. (2009). Study on efficiency of betacyanin extraction from red beetroots. International Journal of Food Science and Technology, 44(12), 2464-2469. https://doi.org/10.1111/j.13652621.2009.02037.x

De Zwart, F. J., Slow, S., Payne, R. J., Lever, M., George, P. M., Gerrard, J. A., \& Chambers, S. T. (2003). Glycine betaine and glycine betaine analogues in common foods. Food Chemistry, $83(2)$, 197-204. https://doi.org/10.1016/S03088146(03)00063-3

Dias, M. G., Camões, M. F. G. F. C., \& Oliveira, L. (2009). Carotenoids in traditional Portuguese fruits and vegetables. Food Chemistry, 113(3), 808-815.

https://doi.org/10.1016/j.foodchem.20 08.08.002

Gilchrist, M., Winyard, P. G., Fulford, J., Anning, C., Shore, A. C., \& Benjamin, N. (2014). Nitric Oxide Dietary nitrate supplementation improves reaction time in type 2 diabetes : Development and application of a novel nitratedepleted beetroot juice placebo. NITRIC OXIDE, 40, 67-74. https://doi.org/10.1016/j.niox.2014.05 .003 
Glaziou, P., Floyd, K., \& Raviglione, M. C. (2015). Global Epidemiology of Tuberculosis. Cold Spring Harb Perspect Med, 5, 1-18. https://doi.org/10.1055/s-00381651492

Glaziou, P., Sismanidis, C., Floyd, K., \& Raviglione, M. (2015). Global Epidemiology of Tuberculosis. 1-17.

Gupta, K. B., Gupta, R., Atreja, A., Verma, M., \& Vishvkarma, S. (n.d.). Tuberculosis and nutrition.

Hobbs, D. A., Goulding, M. G., Nguyen, A., Malaver, T., Walker, C. F., George, T. W., ... Lovegrove, J. A. (2013). Acute Ingestion of Beetroot Bread Increases Endothelium-Independent

Vasodilation and Lowers Diastolic Blood Pressure in Healthy Men: A Randomized Controlled Trial. Journal of Nutrition, 143(9), 1399-1405. https://doi.org/10.3945/jn.113.175778

Indumathi, T., \& Kannikaparameswari. K. (2014). Internationally indexed journal. Int J Pharm Bio Sci, 5(1), 978-982. https://doi.org/0975-6299

Ingle, M., Ingle, M. P., Thorat, S. S., Nimbalkar, C. A., \& Nawkar, R. R. (2017). Nutritional Evaluation of Cookies Enriched with Beetroot ( Beta vulgaris L.) Powder. 6(3), 1888-1896.

Isanaka, S., Mugusi, F., Urassa, W., Willett, W. C., Bosch, R. J., Villamor, E., ... Fawzi, W. W. (2012). Iron deficiency and anemia predict mortality in patients with tuberculosis. Journal of Nutrition, 142(2), 350-357. https://doi.org/10.3945/jn.111.144287

Jastrebova, J., Wittho, C., Grahn, A., Svensson, U., \& Ja, M. (2003). HPLC determination of folates in raw and processed beetroots. 80, 579-588.

Kapadia, G. J., Tokuda, H., Konoshima, T., \& Nishino, H. (1996). Chemoprevention of lung and skin cancer by Beta vulgaris (beet) root extract. Cancer Letters, 100(1-2), 211-214.

https://doi.org/10.1016/0304-

3835(95)04087-0
Karoum, A. O., Mohamed, B. A., Siddig, M. F., \& Bari, E. G. (2009). Anemia in Kassala Area Eastern Sudan. Sudan Journal of Medical Sciences, 4(1), 3135.

Kavalcová, P., Bystrická, J., Tomáš, J., Karovičová, J., Kovarovič, J., \& Lenková, M. (2015). The content of total polyphenols and antioxidant activity in red beetroot. Potravinarstvo, 9(1), 77-83. https://doi.org/10.5219/441

Indonesian Ministry of Health. (2016). Profil Kesehatan Indonesia. In Profil Kesehatan Provinsi Bali.

Indonesian Ministry of Health. (2013). Riset Kesehatan Dasar. 1-268.

Lopez, A. D., \& Mathers, C. D. (2006). Measuring the global burden of disease and epidemiological transitions: 2002-2030. Annals of Tropical Medicine and Parasitology, 100(5-6), 481-499. https://doi.org/10.1179/136485906X9 7417

Monjur, F., \& Rizwan, F. (2014). A Crosssectional Study of Morphological Types of Anemia in Pulmonary Tuberculosis Patient and Associated Risk Indicators in a Selected Hospital of Dhaka City, Bangladesh. Internation Journal of Chemical, Environmental \& Biological Sciences (IJCEBS), 2(4), 215-219.

Muhammad, A. (2005). Determination of iron deficiency in chronic disease anemia by the role of $s T f R-F$ index. (1), 2005.

Murphy, M., Eliot, K., Heuertz, R., \& Weiss, M. (2011). Whole beetroot consumption acutely improves running performance.

https://doi.org/10.1016/j.jand.2011.12 .002

Ninfali, P., \& Angelino, D. (2013). Fitoterapia Nutritional and functional potential of Beta vulgaris cicla and rubra. Fitoterapia, 89, 188-199. https://doi.org/10.1016/j.fitote.2013.0 6.004 
Oliveira, M. G., Delogo, K. N., Oliveira, H. M. de M. G. de, Ruffino-Netto, A., Kritski, A. L., \& Oliveira, M. M. (2014). Anemia in hospitalized patients with pulmonary tuberculosis. Jornal Brasileiro de Pneumologia, 40(4), 403-410. https://doi.org/10.1590/s180637132014000400008

Pallavi Joshi \& Beena Mathur. (2010). Bioavailability of Iron from the Leaf Powders Of Dehydrated Less Utilized Green Leafy Vegetables. Asian J.Exp.Biol.Sci., 1(4), 845-854.

Piso, R. J., Kriz, K., \& Desax, M. (2011). Severe isoniazid related sideroblastic anemia. $3, \quad 2-3$. https://doi.org/10.4081/hr.2011.e2

Presley, T. D., Morgan, A. R., Bechtold, E., Clodfelter, W., Dove, R. W., Jennings, J. M., ... Miller, G. D. (2011). Nitric Oxide Acute effect of a high nitrate diet on brain perfusion in older adults. Nitric Oxide, 24(1), 34-42. https://doi.org/10.1016/j.niox.2010.10 .002

Priya, N. G., Malarvizhi, M., \& Jothi, A. J. (2013). Beet root juice on haemoglobin among adolescent girls. 2(1), 9-13.

Ruditya, D. N. (2015). HUBUNGAN ANTARA KARAKTERISTIK PENDERITA TB DENGAN. Jurnal Berkala Epidemiologi, 3(2), 122-133.

Sei, W. L., Young, A. K., Young, S. Y., Um, S. W., Sang, M. L., Yoo, C. G., ... Yim, J. J. (2006a). The prevalence and evolution of anemia associated with tuberculosis. Journal of Korean Medical Science, 21(6), 1028-1032. https://doi.org/10.3346/jkms.2006.21. 6.1028

Sei, W. L., Young, A. K., Young, S. Y., Um, S. W., Sang, M. L., Yoo, C. G., ... Yim, J. J. (2006b). The prevalence and evolution of anemia associated with tuberculosis. Journal of Korean Medical Science, 21(6), 1028-1032. https://doi.org/10.3346/jkms.2006.21. 6.1028
Shafee, M., Abbas, F., Ashraf, M., Mengal, M. A., Kakar, N., Ahmad, Z., \& Ali, F. (2014). Hematological profile and risk factors associated with pulmonary tuberculosis patients in Quetta, Pakistan. Pakistan Journal of Medical Sciences, 30(1), 36-40. https://doi.org/10.12669/pjms.301.412 9

Suryandari, A. E., \& Happinasari, O. (2015). Perbandingan Kenaikan Kadar $\mathrm{Hb}$ pada Ibu Hamil yang Diberi Fe dengan Fe dan Buah Bit di Wilayah Kerja Puskesmas Purwokerto Selatan. Jurnal Kebidanan, VII(01), 36-47.

Umakanth, M. (2017). Anemia among tuberculosis patient in teaching hospital Batticaloa, Sri Lanka. International Journal of Medical and Health Research, 3(5), 2454-9142. https://doi.org/10.5588/pha.13.0024.5

Umakanth, M., \& Rishikesavan, S. (2017). Prevalence of diabetes mellitus among tuberculosis patient in Batticaloa district , Sri Lanka. 2(2), 21-23. https://doi.org/10.5588/pha.13.0024.5.

Váli, L., Stefanovits-Bányai, É., Szentmihályi, K., Fébel, H., Sárdi, É., Lugasi, A., ... Blázovics, A. (2007). Liver-protecting effects of table beet (Beta vulgaris var. rubra) during ischemia-reperfusion. Nutrition, 23(2), 172-178.

https://doi.org/10.1016/j.nut.2006.11. 004

Vanhatalo, A., Bailey, S. J., Blackwell, J. R., DiMenna, F. J., Pavey, T. G., Wilkerson, D. P., ... Jones, A. M. (2010). Acute and chronic effects of dietary nitrate supplementation on blood pressure and the physiological responses to moderate-intensity and incremental exercise. American Journal of Physiology - Regulatory Integrative and Comparative Physiology, 299(4), 1121-1131. https://doi.org/10.1152/ajpregu.00206 .2010

WHO. (2014). Global tuberculosis report 2014 WHO Library Cataloguing-in- 
Publication Data. Who, 1-171.

Wootton-Beard, P. C., Moran, A., \& Ryan, L. (2011). Stability of the total antioxidant capacity and total polyphenol content of 23 commercially available vegetable juices before and after in vitro digestion measured by FRAP, DPPH, ABTS and Folin-Ciocalteu methods. Food Research International, 44(1), 217-224.

https://doi.org/10.1016/j.foodres.2010 .10 .033

Wruss, J., Waldenberger, G., Huemer, S., Uygun, P., Lanzerstorfer, P., Müller, U., ... Weghuber, J. (2015). Compositional characteristics of commercial beetroot products and beetroot juice prepared from seven beetroot varieties grown in Upper Austria. Journal of Food Composition and Analysis, 42(3), 46-55. https://doi.org/10.1016/j.jfca.2015.03. 005 